\title{
IDIOSYNCRATIC VOLATILITY AND HERD BEHAVIOR: INDONESIA STOCK MARKET CASE
}

\author{
Buddi Wibowo \\ Universitas Indonesia, Indonesia
}

\begin{abstract}
Anomalies revealed by various research of asset pricing models indicate the presence of other risk factors which have not been included in the model. Even the most recent models such as the Fama-French Five Factor still leave several other risk factors included in the error terms produced by the model. An empirical test that tests whether this idiosyncratic risk significantly affects stock returns becomes necessary and urgent in order to obtain a solid theoretical understanding. Empirical tests in emerging market stock markets such as the Indonesia stock exchange are important in sharpening and enriching the understanding of idiosyncratic risk because transactions in emerging market stock markets are more likely to be influenced by the existence of herding behavior where foreign investors or large investors can often direct trading in several stocks. The empirical test of the idiosyncratic risk and herd behavior correlation in the Indonesia stock exchanges shows herd behavior, especially in stocks that have high idiosyncratic risk and occur in the normal period, not in the crisis period. Herd behavior still avoids too much risk taking, as in times of high uncertainty such as during the crisis period.
\end{abstract}

Keywords: idiosyncratic volatility, herd behavior, crises, Five Factor Model

\section{VOLATILITAS IDIOSYNCRATIK DAN PERILAKU KAWANAN: KASUS PASAR SAHAM INDONESIA}

\begin{abstract}
ABSTRAK
Anomali yang terungkap oleh berbagai uji empirik model asset pricing menunjukkan adanya faktor risiko lain yang belum dimasukkan ke dalam model. Model yang paling mutakhir pun seperti Fama-French Five Factor masih menyisakan beberapa faktor risiko lain yang tercakup di dalam error term yang dihasilkan model tersebut. Uji empirik yang menguji apakah risiko yang bersifat idiosyncratik ini berhubungan dengan imbal hasil saham menjadi perlu dan mendesak untuk dapat memperoleh pemahaman teoretis yang solid. Uji empirik di pasar saham negara berkembang seperti bursa saham Indonesia menjadi penting dalam upaya mempertajam dan memperkaya pemahaman atas risiko idiosyncratik ini karena transaksi di pasar saham negara berkembang diduga cenderung dipengaruhi oleh adanya herding behavior dimana investor asing atau investor besar seringkali dapat mengarahkan perdagangan beberapa saham. Uji empirik atas hubungan antara idiosyncratic volatility dan herd behavior di pasar saham Indonesia menunjukkan herd behavior terutama terjadi pada saham yang memiliki risiko idiosyncratik yang tinggi dan terjadi di periode normal, bukan pada periode krisis. Herd behavior masih menghindari pengambilan risiko yang terlalu besar seperti pada saat dengan ketidakpastian yang tinggi seperti saat periode krisis.
\end{abstract}

Kata-kata Kunci: risiko idiosyncratik, perilaku kawanan, krisis, model Five Factor

Korespondensi: Dr. Buddi Wibowo. Fakultas Ekonomi dan Bisnis Universitas Indonesia, Jln. Prof. DR. Sumitro Djojohadikusumo, Kukusan, Kec. Beji, Kota Depok, Jawa Barat 16424. Email: buddi.wibowo@ui.ac.id 
Jurnal Bisnis dan Manajemen, Volume 20, No. 1, March 2019, p. 49-58

\section{INTRODUCTION}

CAPM developed by Sharpe (1964), Treynor (1961), and Lintner (1965) is the first asset pricing theory that states returns are a function of a risk factor only. This model states that beta coefficient which reflects systematic risk is the only factor associated with security return. Proposing this view, CAPM also indirectly states that all other variables which are not included in the model do not have a significant effect on return. This is reflected in the characteristic of error terms which are result by estimating the CAPM model. Average of error terms is zero. The initial empirical test of the CAPM model conducted by Fama and MacBeth (1973) proves that regression of returns on error terms produces an insignificant coefficient, so we may conclude error terms do not affect return.

Other risk factors which are not included in the CAPM model are often referred as an idiosyncratic risk. Idiosyncratic risk can be eliminated or eliminated through establishing a fully-diversified investment portfolio. The return of a fully-diversified portfolio proven by Fama and MacBeth (1973) is not affected by the estimated term error of the CAPM model, which means risk factors other than market beta, namely systematic market risk, have no effect on returns and therefore we may ignore idiosyncratic risk when using CAPM.

Contrasting with CAPM proposition, empirical asset pricing research after Fama and MacBeth (1973) find several anomalies. For example, Basu (1977) finds that low price per earnings $(\mathrm{P} / \mathrm{E})$ ratio stock portfolio tends to produce a higher return than stocks with a high $\mathrm{P} /$ $\mathrm{E}$ ratio. The $\mathrm{P} / \mathrm{E}$ ratio seems become a risk factor that significantly affects stock returns. Anomaly was also found by Banz (1981) where companies with low market capitalization empirically produce higher average annual returns than companies with high market capitalization. This is called size or small-firm effect, the size of the company's assets appears to be a significant risk factor. Another anomaly was value-growth stock, a stock called value stock which is a stock that has a high book value of equity-to-market value of equity ratio (BE / ME), yields far higher returns than growth stock which has low $\mathrm{BE} / \mathrm{ME}$ ratio.

Answering the controversy over empirical tests that show some anomalies over the CAPM model, Fama and French (1992) investigate whether CAPM beta is indeed no longer the only predictor of stock returns. Then, they find the bookto-market ratio $(\mathrm{BE} / \mathrm{ME})$ and size of asset have high explanatory power to predict stock returns.

Price-earnings (P/E), small-firm (size), bookto-market (BE / ME), momentum and long-term reversal effects are still a puzzle phenomenon in financial empirical research. Fama and French (1992) state that these effects can be explained as manifestations of risk premium. Using the theoretical basis of arbitrage pricing theory, Fama and French (1992) introduce a three-factor model. This model reveals risk as a stock sensitivity to three factors, namely: market risk premium (beta CAPM), asset-size factor measured by portfolio returns which reflects the relative small return 
Jurnal Bisnis dan Manajemen, Volume 20, No. 1, March 2019, p. 49-58

versus large firm portfolio returns, and $\mathrm{BE} / \mathrm{ME}$ ratio risk factor which is measured by differencing the high $\mathrm{BE} / \mathrm{ME}$ ratio portfolio returns from the low BE / ME ratio portfolio returns.

Taking similar Fama-French's argument, Carhart (1997) developed an extension of FamaFrench Three Factor model by adding momentum risk factor which is a reflection of the relative return of winners versus losers stock portfolio. This momentum anomaly arises from behavioral finance studies which show a drastic pattern of price increases in the short term (price momentum) and then fall drastically and will rise again in the long term (price reversal). De Bondt and Thaler (1985) and Jegadeesh and Titman (1993) are among many empirical research that reveal this momentum anomaly. However, the application of the Carhart Four-factor model is relatively rare in empiric financial research compared to the FamaFrench Three Factor model which is widely accepted and considered as having strong explanatory power to explain the relationship between returns and risk factors which cannot be explained by the CAPM standard model. However, according to Novy-Marx (2013), Wei, Xie, and Titman (2001) and several other researchers, the Fama-French Three Factor model is an imperfect model because it neglects the variation in average returns related to profitability and investment. Therefore, Fama and French (2015) refined the model to become the Fama-French Five Factor, where this model is designed to capture the sensitivity of profitability and investment factors.
Even though the asset pricing model which we are using is the most comprehensive model such as the Fama-French Five Factor model, there is still a suspicion that the error term generated from the model produces a significant magnitude and has a meaningful systematic pattern. This error term becomes an idiosyncratic risk which significantly affects returns. This guess comes from the reality that investors cannot always form a perfectly diversified portfolio. According to Nartea, Wu, dan Liu (2013), one reason that causes investors not to form well-diversified portfolios is because of transaction costs so that most investors have only few stocks in their portfolios. Goetzmann and Kumar (2008) shows that based on a sample of 62,000 household U.S investors in the 1991-1996 period, more than $25 \%$ of investors only have one stock, more than $50 \%$ have no more than three shares, and less than $10 \%$ of investors has more than 10 shares. Even though according to Campbell, Lettau, Malkiel, and Xu (2001) to achieve a portfolio with perfect diversification requires a minimum of around 50 shares.

After reviewing the results of those studies, we may conclude that idiosyncratic risk is one of the risk factors which influences expected return and need to be taken into account in the asset pricing model. Malkiel and Xu (1999) state that idiosyncratic volatility is not observed and is latent variable. There are two approaches in estimating idiosyncratic risk, first method introduced by Campbell et al. (2001) which follow an indirect decomposition method and second method is a direct decomposition method which based on an 
Jurnal Bisnis dan Manajemen, Volume 20, No. 1, March 2019, p. 49-58

asset pricing models such as three-factor model or five-factor model popularized by Fama and French $(1992,2015)$ and then measure standard deviation of its error terms.

Latest empirical research on idiosyncratic risk relates it to investors' herd behavior where most investors make their decision not based on information but only follow opinion leaders or market makers (Vo and Phan, 2019). Because of herd behavior, market prices swing and move follow a systematic pattern which subsequently create significant idiosyncratic risk. Vo and Phan (2019) show evidence that each type of stock portfolio have a specific herding behavior and the idiosyncratic volatility relationship.

As a capital market in developing country whose relatively narrow investor base and has a strong tendency for foreign investors to move the market, the Indonesia stock exchange is the right object to test how significant idiosyncratic risk affect herd behavior. The author will use standard deviation of residuals generated by the Five Factor model (Fama and French, 2015) to measure idiosyncratic risk because it is still considered best model in explaining returns than the Carhardt-4 factor model, 3-factor model, or CAPM. The sample from this study is stocks listed on the Indonesia Stock Exchange between 2010-2017.

\section{LITERATURE REVIEW}

Ang, Hodrick, Xing, and Zhang (2009) prove that stock indices in US and G7 countries and other developed countries are affected negatively by idiosyncratic risk. In addition, they also find that idiosyncratic risk moves in opposite direction with expected return in the individual stock level. In other words, high idiosyncratic volatility stock in the past will have a much lower return than stocks with low past idiosyncratic volatility. This is supported by Huang, Liu, Rhee, and Zhang (2010) who show stock returns in the Taiwan market negatively correlated with its idiosyncratic risk.

Compared to above research, Fu (2009) find different results. Fu (2009) show that stock portfolios which have high idiosyncratic volatility have higher average returns than portfolios with low idiosyncratic volatility. $\mathrm{Fu}$ (2009) also find that idiosyncratic volatility is time-varying and calculate the expected idiosyncratic volatility with E-GARCH. Fu (2009) show there is a positive effect of idiosyncratic volatility on the expected stock return. This is supported by Miralles-Marcelo et al (2012) finding that idiosyncratic risk positively affect returns in the Spanish stock exchanges. $\mathrm{Fu}$ (2009) results a different conclusion with previous researcher such as Bali and Cakici (2006) and Bali, Cakici, Yan, and Zhang, (2005) who find idiosyncratic risk have no significant effect on stock returns in the US stock market.

Herd behavior is investor behavior which follow other investor decision so that most of investor have a similar trading pattern even though they have no specific information or reasons why majority of investors follow a similar trading decision (Litimi, BenSaïda, and Bouraoui, 2016). If this phenomenon takes place in the long period and the stock price move away and around its 
Jurnal Bisnis dan Manajemen, Volume 20, No. 1, March 2019, p. 49-58

intrinsic value, herding consequently generates the stock volatility (Vo and Phan, 2019). Nartea et al., (2013) show herding occurs in majority of stock market in emerging market.

Herding affects stock price volatility because herding reduces heterogeneity among investors (Xu, Jiang, Chan, \& Wu, 2017; (Nianhang et al., 2017;Schmitt \& Westerhoff, 2017). As idiosyncratic volatility can be eliminated by diversification in portfolios, herd behavior creates an identical trading pattern among investors and directly affect stock price volatility. Litimi et al. (2016) show many individual investors do not hold diversified portfolios and they need higher return to compensate higher idiosyncratic risk of their stocks.

Herd behavior differences between groups of stocks which have different level of idiosyncratic volatitility is an empirical research problem. Previous empirical tests of this research question have a mixed result (Vo and Phan, 2019). We also do not have a clear explanation from previous research whether financial crises has a significant effect to correlation of idiosyncratic volatility and herd behavior. Considering this puzzle, academic research should address this research problem, especially in the emerging market context, as Indonesia stock exchanges. I propose research hypothesis that idiosyncratic risk has a significant effect on stock returns and the relationship between this two variable are affected by herd behavior among investor and crises period which is disagreement among investors occurs in this period because of high uncertainty.
Disagreement occurs in determining relevant risk factors and its effect to stock return. More severe disagreement drives higher idiosyncratic risk.

\section{METHODS}

The research uses the direct decomposition method in which idiosyncratic volatility is estimated as the residual variance generated by the expected return model. Some researchers who have used this method, among others: Ang, Hodrick, Xing, and Zhang (2009), Fu (2009), Bali et al. (2005), Huang et al. (2010), and (Miralles-Marcelo et al., 2012). Estimating the value of idiosyncratic volatility, all of them use a three-factor model (Fama and French, 1992) as the expected return model. Whereas (Vo \& Phan, 2019) use market model as the expected return model. Investigating Indonesia stock market, my research uses Fama-French Five Factor Model as expected return model to generate idiosyncratic component of stock return and estimate idiosyncratic risk based on it.

Fama-French Five Factor Model proposes a relationship between stock returns and five risk factors which are: market risk premium $\left(R_{m}-R_{f}\right)$, corporate size risk premium (SMB), book value to market value risk premium (HML), robust minus weak ratio of operating profitability (RMW), and conservative versus aggressive of investment (CMA). Detail measurement method of all variables is explained in Table 1.

Using following model (1), error term $\left(e_{i, \tau}\right)$ can be generated and measured its standard deviation which is the idiosyncratic risk: 
Jurnal Bisnis dan Manajemen, Volume 20, No. 1, March 2019, p. 49-58

$$
\begin{aligned}
R_{i, \tau}-R_{f, \tau}= & a_{i, t}+b_{i, t}\left[\left(R_{m, \tau}\right)-R_{f, \tau}\right]+ \\
& s_{i, t}\left(S M B_{\tau}\right)+h_{i, t}\left(H M L_{\tau}\right)+ \\
& r_{i, t}\left(R M W_{\tau}\right)+c_{i, t}\left(C M A_{\tau}\right)+e_{i, \tau}
\end{aligned}
$$

\begin{tabular}{|c|c|}
\hline Variable & Notes \\
\hline $\mathrm{R}_{\mathrm{m}}-\mathrm{R}_{\mathrm{f}}$ & Market risk premium \\
\hline SMB & $\begin{array}{l}\text { SMB is difference between return } \\
\text { of stock portfolio consists of small } \\
\text { size-company and return of big } \\
\text { size-company }\end{array}$ \\
\hline HML & $\begin{array}{l}\mathrm{HML} \text { is estimated based on book- } \\
\text { to-market ratio }(\mathrm{B} / \mathrm{M}) \text {. HML is } \\
\text { return portfolio of High } \mathrm{B} / \mathrm{M} \text { ratio- } \\
\text { company minus return of Low } \\
\mathrm{B} / \mathrm{M} \text { ratio-company. }\end{array}$ \\
\hline RMW & $\begin{array}{l}\text { RMW is estimated based on } \\
\text { operating profitability ratio (OP) } \\
\text { which ratio between perating } \\
\text { income minus interest expense and } \\
\text { total shareholder's equity. RMW is } \\
\text { High OP ratio-firm portfolio return } \\
\text { minus Low OP ratio-firm portfolio } \\
\text { return. }\end{array}$ \\
\hline CMA & $\begin{array}{l}\text { CMA is estimated based on } \\
\text { investment ratio (Inv). CMA is } \\
\text { High Investment ratio-firm } \\
\text { portfolio return minus Low } \\
\text { Investment ratio-firm portfolio } \\
\text { return. }\end{array}$ \\
\hline
\end{tabular}

Table 1. Fama-French Five Factor Model

Source: Fama and French (2015)

Idiosyncratic Volatility (IVOL) of each stock is standard deviation of error term generated from model (1):

$$
\operatorname{IVOL} L_{i, \tau}=\sqrt{\operatorname{Var}\left(e_{i, \tau}\right)}
$$

Idiosyncratic volatilities are assumed to increase in period with high level of uncertainty. Disagreement among investors occurs in the period of high uncertainty, like crises period. Disagreement occurs in determining relevant risk factors and its effect to stock return (Vo and Phan, 2019). It is very difficult to predict price movement in the period of crises which is characterized by radical changes of investment rule of the game, market actors and their investing behavior, like what have happened in 2008-2009 and 2013.

When herd behavior has an significant effect in stock market, individual stock returns tend to slightly fluctuate around market returns and drive market return dispersion down. Christie and Huang (2006) developed CSSD Method where we can measure the return dispersion with the following specification:

$$
\operatorname{CSSD}_{t}=\sqrt{\frac{\sum_{i=1}^{N}\left(R_{i, t}-R_{m, t}\right)^{2}}{(N-1)}}
$$

The rational asset pricing model states that return dispersions relate linearly with market returns. When there is a large price swing in the market because of disagreement among investors, relationship between return dispersion and market return becomes non-linear where return dispersion become very low during periods of relatively high herd behavior exists. Hence, following Vo and Phan (2019), we may use equation (4) to identify herd behavior:

$$
C S S D_{\tau}=\gamma_{0}+\gamma_{1}\left|R_{m, t}\right|+\gamma_{2} R_{m, t}^{2}+e_{t} \ldots .
$$

Thus, a negative and statistically significant of coefficient $\gamma_{2}$ implies the decrease of return dispersion from market returns which indicates the presence of herding.

Based on its idiosyncratic volatility, stocks are separated into 3 groups: High, Medium, and Low 
Jurnal Bisnis dan Manajemen, Volume 20, No. 1, March 2019, p. 49-58

idiosyncratic volatility which equation (4) is estimated for each group so we have three estimation result of equation (4). Comparing the regression coefficient generated from 3 groups of idiosyncratic volatility, we get a robust test whether herd behavior differs between groups of idiosyncratic volatility.

\section{RESULTS AND DISCUSSION}

Using Fama-French Five Factor as the expected return model and grouping its generated error terms into three categories based on its average, we obtain descriptive statistics as can be seen in Table 2.

Stock groups that have the high idiosyncratic volatility have low standard deviation. This indicate that there is an increasingly strong investor behavior conformity in stocks which have high idiosyncratic volatility. High conformity is reflected in similar trading patterns because of indifferent quality of information held by average investors or because of similar strategies among retail investors who follow opinion leaders.

Table 2. Statistic Descriptive Idiosyncratic Volatility per Groups

\begin{tabular}{lccc}
\hline & \multicolumn{3}{c}{$\begin{array}{c}\text { Idiosyncratic Volatility } \\
\text { (\%) Group }\end{array}$} \\
\hline & High & Medium & Low \\
\hline Average & 4.57 & 3.78 & 2.15 \\
Standard & & & \\
Deviation & 1.48 & 1.65 & 2.48 \\
Maximum & 5.78 & 4.25 & 5.21 \\
Minimum & 3.58 & 2.78 & 2.1 \\
\hline
\end{tabular}

Idiosyncratic volatility tends to be high during a financial crisis with a very large standard deviation (see Table 3). This gives an indication that during a crisis investors trade based on their own private information which is significantly different among them.

Table 3. Statistic Descriptive Idiosyncratic Volatility per Period

\begin{tabular}{lcc}
\hline & $\begin{array}{c}\text { Idiosyncratic Volatility (\%) } \\
\text { Period }\end{array}$ \\
\hline & Crises & $\begin{array}{c}\text { No } \\
\text { Crises }\end{array}$ \\
\hline Average & 5.38 & 1.83 \\
Standard & & \\
Deviation & 1.48 & 1.65 \\
Maximum & 5.78 & 4.25 \\
Minimum & 3.58 & 2.78 \\
\hline
\end{tabular}

Conformity was weakened during the crisis, the role of opinion leaders or big players in directing retail investors' trades experiences a significant weakening effect during the crisis. During a turbulent market, each investor tends to seek and interprets their own private information independently so that idiosyncratic volatility becomes high. Herd behavior tends to weaken in times of crisis which has high uncertainty of stock price movement and rapidly changing information.

Estimation of equation (4) support claim that herd behavior is relatively low in period of crises (look Table 4). Herd behavior measure, parameter $\gamma_{2}$, are significant in the priod of crises and normal period, but magnitude of $\gamma_{2}$ in the period of crises is two fold than in the nomral period. Herd behaviors are stronger in the normal period which retail investors tend to mimic opinion leaders or big market players, such as foreign investor anf institutional investors. 
Jurnal Bisnis dan Manajemen, Volume 20, No. 1, March 2019, p. 49-58

Table 4. Regression Result of CSSD per Period

\begin{tabular}{|c|c|c|c|c|}
\hline & \multicolumn{2}{|c|}{ Crises } & \multicolumn{2}{|c|}{ No Crises } \\
\hline & Coefficient & $\begin{array}{l}t \\
\text { stat }\end{array}$ & Coefficient & t stat \\
\hline & & 1.8 & & \\
\hline$\gamma_{0}$ & $2.13 *$ & $\begin{array}{c}7 \\
0.8\end{array}$ & 2.24 & 1.02 \\
\hline$\gamma_{1}$ & 3.15 & $\begin{array}{c}2 \\
2.1\end{array}$ & 3.47 & 0.95 \\
\hline$\gamma_{2}$ & $2.53^{* *}$ & 5 & $5.57 * * *$ & 3.47 \\
\hline
\end{tabular}

Herd behavior tends to be much stronger in stock groups which have high idiosyncratic volatility. Average herd behavior parameter of stock portfolio with high idiosyncratic volatility is higher than other portfolios which has lower idiosyncratic volatility (see Table 5). Herd behavior and idiosyncratic volatility relationship significance increases monotonically from stock groups with low idiosyncratic volatility, to the medium and then to high idiosyncratic volatility groups. This indicates herd behaviors or imitating behaviors among investors are much stronger in groups with high idiosyncratic volatility. High idiosyncratic volatility reflects many other risk factors that have not been included in the FamaFrench Factor Model. Most investors refer stocks with high idiosyncratic risk characteristics as stocks that are difficult to predict their price movements and its determinant so that it is safer for retail investors to follow leader opinion and big players (Jegadeesh and Titman, 1993).
Table 5. Herd Behavior per Group of Idiosyncratic Volatility

Idiosyncratic Volatility

Group

\begin{tabular}{lccc}
\hline $\begin{array}{l}\text { Herd Behavior } \\
\text { Parameter }\left(\boldsymbol{\gamma}_{\mathbf{2}}\right)\end{array}$ & High & Medium & Low \\
\hline Average & 4.57 & 3.78 & 2.15 \\
Standard & & & \\
Deviation & 1.48 & 1.65 & 2.48 \\
Maximum & 5.98 & 4.25 & 5.21 \\
Minimum & 2.13 & 2.78 & 2.1 \\
\hline
\end{tabular}

Imitating behavior is significantly different between type of stock, especially stock which have no deterministic time series returns pattern. High idiosyncratic volatility shows the prediction of the Fama-French Five Factor results a high volatility of error term that indicates high uncertainty of idiosyncratic risk where the factors affecting stock returns significantly changes over time. With high idiosyncratic volatility, the stock price movement pattern tends to be a pure random walk so it is difficult to predict its future position. Such stocks tend to be a speculation tool for big players so that herd behaviors tend to be stronger in stocks with high idiosyncratic volatility.

Herd behavior in groups with high idiosyncratic stocks is stronger in the non-crises period (See Table 6). High market uncertainty during the crisis caused investors to reduce speculative trading, including speculative actions by following the big player trading pattern. In general, the similar situation also happens in groups of stocks with medium and low idiosyncratic volatility, herd behavior is much stronger in the normal / non crises period. 
Jurnal Bisnis dan Manajemen, Volume 20, No. 1, March 2019, p. 49-58

Table 6. Herd Behavior per Group of

Idiosyncratic Volatility and Per Period

\begin{tabular}{|c|c|c|c|c|c|c|}
\hline \multirow{2}{*}{$\begin{array}{l}\text { Herd } \\
\text { Behavior } \\
\text { Parameter } \\
\quad \gamma_{2} \\
\end{array}$} & \multicolumn{2}{|c|}{ High } & \multicolumn{2}{|c|}{ Medium } & \multicolumn{2}{|c|}{ Low } \\
\hline & Crises & $\begin{array}{c}\text { No } \\
\text { Crises }\end{array}$ & Crises & $\begin{array}{c}\text { No } \\
\text { Crises }\end{array}$ & Crises & $\begin{array}{c}\text { No } \\
\text { Crises }\end{array}$ \\
\hline Average & 3.25 & 5.87 & 3.11 & 3.86 & 2.15 & 2.56 \\
\hline $\begin{array}{l}\text { Standard } \\
\text { Deviation }\end{array}$ & 1.76 & 1.12 & 1.84 & 1.37 & 2.13 & 2.51 \\
\hline Maximum & 4.72 & 5.98 & 4.01 & 4.25 & 2.21 & 2.87 \\
\hline Minimum & 2.13 & 2.81 & 2.78 & 2.81 & 2.11 & 2.21 \\
\hline
\end{tabular}

Idiosyncratic volatility reflects

undiversified firm-specific risk which comes from transparency level of the firm. Ang, et al.(2009) state that less transparent firms tend to have low idiosyncratic volatility. Because of limited information, price changes usually are determined by noisy trading activities and herd behavior. Schmitt and Westerhoff (2017) propose the informed trading hypothesis which predicts that idiosyncratic risk has a strong negative correlation with mispricing. Stock with high level of idiosyncratic volatility are more likely traded by informed traders who are able to assess stock's intrinsic values (Nartea et al, 2013). In the case of herd behavior, big players and opinion leaders are assumed to be an informed trader which their trading activities followed by retail investors (Litimi et al (2016).

\section{CONCLUSION}

Herd behaviors or imitating behaviors among investors are much stronger in groups with high idiosyncratic volatility. Imitating behavior is significantly different between type of stock, especially stock which have random pattern of stock returns. Retail invetors tend to follow some big players' trading pattern for stock with high idiosyncratic volatility in the normal period, rather than in period of crises which price movements are more unpredictable.

\section{REFERENCES}

Ang, A., Hodrick, R. J., Xing, Y., \& Zhang, X. (2009). High idiosyncratic volatility and low returns: International and further U.S. evidence. Journal of Financial Economics. https://doi.org/10.1016/j.jfineco.2007.12.005

Bali, T. G., \& Cakici, N. (2006). Idiosyncratic Volatility and the Cross-Section of Expected Returns. SSRN. https://doi.org/10.2139/ssrn.886717

Bali, T. G., Cakici, N., Yan, X., \& Zhang, Z. (2005). Does idiosyncratic risk really matter? Journal of Finance. https://doi.org/10.1111/j.15406261.2005.00750.x

Banz, R. W. (1981). The relationship between return and market value of common stocks. Journal of Financial Economics. https://doi.org/10.1016/0304405X(81)90018-0

Basu, S. (1977). Investment performance of common stocks in relation to their priceearnings ratio: A Test of the efficient market hypothesis. The Journal of Finance. https://doi.org/10.1111/j.15406261.1977.tb01979.x

Campbell, J. Y., Lettau, M., Malkiel, B. G., \& Xu, Y. (2001). Have individual stocks become more volatile? An empirical exploration of idiosyncratic risk. Journal of Finance. https://doi.org/10.1111/0022-1082.00318

Carhart, M. M. (1997). On persistence in mutual fund performance. Journal of Finance. https://doi.org/10.1111/j.15406261.1997.tb03808.x

Christie, W. G., \& Huang, R. D. (2006). Following the Pied Piper: Do Individual Returns Herd around the Market? Financial Analysts Journal. https://doi.org/10.2469/faj.v51.n4.1918

De Bondt, W. F. M., \& Thaler, R. (1985). Does 
Jurnal Bisnis dan Manajemen, Volume 20, No. 1, March 2019, p. 49-58

the Stock Market Overreact? The Journal of

Finance. https://doi.org/10.1111/j.1540-

6261.1985.tb05004.x

Eugene F. Fama and James D. MacBeth. (1973).

Risk, Return, and Equilibrium: Empirical

Tests. The Journal of Political Economy. https://doi.org/10.1017/CBO9781107415324. 004

Fama, E. F., \& French, K. R. (2015). A five-factor asset pricing model. Journal of Financial Economics.

https://doi.org/10.1016/j.jfineco.2014.10.010

Fama, E. F., and French, K. R. (1992). The Cross-

Section of Expected Stock Returns. The

Journal of Finance.

https://doi.org/10.1111/j.1540-

6261.1992.tb04398.x

Fu, F. (2009). Idiosyncratic risk and the crosssection of expected stock returns. Journal of Financial Economics.

https://doi.org/10.1016/j.jfineco.2008.02.003

Goetzmann, W. N., \& Kumar, A. (2008). Equity portfolio diversification. Review of Finance. https://doi.org/10.1093/rof/rfn005

Huang, W., Liu, Q., Rhee, S. G., \& Zhang, L. (2010). Return reversals, idiosyncratic risk, and expected returns. Review of Financial Studies. https://doi.org/10.1093/rfs/hhp015

Jegadeesh, N., \& Titman, S. (1993). Returns to Buying Winners and Selling Losers: Implications for Stock Market Efficiency. The Journal of Finance.

https://doi.org/10.1111/j.15406261.1993.tb04702.x

Lintner, J. (1965). Security prices, risk, and maximal gains from diversification. The Journal of Finance.

https://doi.org/10.1111/j.15406261.1965.tb02930.x

Litimi, H., BenSaïda, A., \& Bouraoui, O. (2016). Herding and excessive risk in the American stock market: A sectoral analysis. Research in International Business and Finance. https://doi.org/10.1016/j.ribaf.2016.03.008

Malkiel, B., \& Xu, Y. (1999). The structure of stock market volatility. Financial Research.

Miralles-Marcelo, J. L., Miralles-Quirós, M. del M., \& Miralles-Quirós, J. L. (2012). Asset pricing with idiosyncratic risk: The Spanish case. International Review of Economics and
Finance.

https://doi.org/10.1016/j.iref.2011.07.004

Nartea, G. V., Wu, J., \& Liu, Z. (2013). Does idiosyncratic volatility matter in emerging markets? Evidence from China. Journal of International Financial Markets, Institutions and Money.

https://doi.org/10.1016/j.intfin.2013.09.002

Novy-Marx, R. (2013). The other side of value:

The gross profitability premium. Journal of

Financial Economics.

https://doi.org/10.1016/j.jfineco.2013.01.003

Schmitt, N., \& Westerhoff, F. (2017). Herding behaviour and volatility clustering in financial markets. Quantitative Finance. https://doi.org/10.1080/14697688.2016.1267 391

Sharpe, W. F. (1964). Capital asset prices: A Theory of market equilibrium under conditions of risk. The Journal of Finance. https://doi.org/10.1111/j.15406261.1964.tb02865.x

Treynor, J. L. (1961). Market Value, Time, and Risk (revised manuscript). SSRN. https://doi.org/10.2139/ssrn.2600356

Vo, X. V., \& Phan, D. B. A. (2019). Herd behavior and idiosyncratic volatility in a frontier market. Pacific Basin Finance Journal. https://doi.org/10.1016/j.pacfin.2018.10.005

Wei, K. C. J., Xie, F., \& Titman, S. (2001). Capital Investments and Stock Returns. SSRN. https://doi.org/10.2139/ssrn.268538

Xu, N., Jiang, X., Chan, K. C., \& Wu, S. (2017). Analyst Herding and Stock Price Crash Risk: Evidence from China. Journal of International Financial Management and Accounting. https://doi.org/10.1111/jifm.12062 